\title{
Growth and Survival of Mangrove Seedlings under Different Levels of Salinity and Drought Stress
}

\author{
Nit Lyn B. Estomata and Pamela P. Abit \\ Department of Biological Science, Visayas State University, Baybay City, Leyte 6521- \\ A, Philippines
}

\begin{abstract}
Water availability and salinity are determinants of growth, survival and establishment of mangrove species. This study aimed to compare the ability of the mangrove species to survive extreme water stress, and to determine differences in growth performance and biomass allocation between mangrove species grown in different water levels and saline conditions. Seedlings of Lumnitzera racemosa, Rhizophora apiculata, R. mucronata and Avicennia marina were used. A dry-down experiment was done to compare the ability of mangrove species from different zonations to survive drought stress by evaluating survival rates after re-watering consequent to drought exposure. The different mangrove species were grown at different water levels (dry, well-watered, flooded) and different salinity levels such as low (3-5 ppt), high (25-27 ppt) and pure seawater (32 ppt) to evaluate the growth performance and biomass allocation of the mangrove seedlings.

$L$. racemosa was the most drought tolerant, followed by $R$. mucronata and $A$. marina while $R$. apiculata was the most drought sensitive. There is a possibility that $A$. marina may displace the current distribution of $R$. apiculata in the middle zone while the distribution of L. racemosa and R. mucronata in the landward and middle zone, respectively could be retained. The number of leaves of $A$. marina was significantly higher than $R$. apiculata and $R$. mucronata but was only comparable to that of $L$. racemosa across all salinity levels. L. racemosa was only significantly different from the two Rhizophora spp. under pure saline treatment. Root length of A. marina was significantly higher than $R$. apiculata but statistically similar to $R$. mucronata and $L$. racemosa. The capacity for root growth may allow roots to exploit water from dry soils and could correspond to the drought tolerance of A. marina, R. mucronata and L. racemosa. There was no significant effect of water and salinity stresses on the biomass allocation.
\end{abstract}

Keywords: drought stress, water potential, salinity, survival

Correspondence: Pamela P. Abit Address: Department of Biological Sciences, Visayas State University, Baybay City, Leyte, 6521-A Philippines. Tel: 335-4007 E-mail: pamela_abit@ yahoo.com

DOI: $10.32945 /$ atr3326.2011 


\section{INTRODUCTION}

The mangrove forest known as 'rainforest by the sea', which is distributed in the tropical and sub-tropical regions, is one of the most important coastal ecosystems in the world in terms of primary production and coastal protection (Clark, 1992). It grows along tidal mudflats and shallow coastal areas extending along rivers, streams and their tributaries where the water is generally brackish (Melana and Gonzales, 1996). Mangroves are facultative halophytes that have the ability to grow in either fresh or saltwater depending on which is available (Calumpong and Meñez, 1997).

Mangrove trees grow in soil that is more or less permanently waterlogged and in water with fluctuating salinity that may be as high as that of the open sea (Hogarth, 1999). Mangroves form a protective buffer zone, stabilize sediments, and reduce shoreline and riverbank erosion, regulate flooding, recycle nutrients, serve as shelter for birds and other animals and protect people and their homes by acting as a natural shield against storms and tidal waves, which also in turn provide people with means of livelihood like fishing, shrimp and prawn culture, salt-making and farming (Primavera et al., 2004). In addition, mangroves provide nursery grounds for fish, prawns, and crabs and support the fishery industry. The arch-shaped roots and the finger tube root structure of Avicennia officinalis and A. marina serve as very good nurseries and hiding places for many important sea animals (PCARRD, 1991), hence, mangrove protection, rehabilitation and reforestation are very important.

Water availability and salinity are two important determinants of growth, survival and establishment of mangrove species. The spatial pattern of species composition is greatly affected by the degree of salinity, tidal inundation and other edaphic factors (Enoki et al., 2009). In addition, many other biological processes such as dispersal (Clarke $e t$ al., 2001), competition and herbivory (Feller, 2002) also vary relatively along tidal gradients (Clarke and Myerscough, 1993). Water availability plays a vital role for the mangrove species, since mangrove usually disperse their offspring by water. In areas where flooding occurs, water availability enables the seedling to float in the water, which helps the 
seedling to land in areas where growth is more favorable. With the current changing in climate, it is expected to cause an increase in temperature, resulting in greater evaporation and increased soil moisture deficits. An increase in global temperatures is therefore likely to increase the severity or duration of drought conditions. Drought is a form of water stress that may influence growth of a plant species. During drought, it takes time for the seedling to grow (Doubenmire, 1974) since some of the physiological processes are affected.

The differential ability of the mangrove seedlings to withstand extreme water and saline conditions may influence plant survival, which consequently limits species distribution in a landscape. Seedlings of Avicennia, for instance, as well as Rhizophora mucronata do better in high saline concentrations than Sonneratia lanceolata, which are intolerant to low saline concentrations (Hogarth, 1999).

The seedling stage is the most critical in the life history of a mangrove species, since this stage has often high mortality rates (Dodd and Donovan, 1998). Thus, this study was conducted to provide information on how mangrove seedlings cope with abiotic stresses such as different levels of water availability and salinity under controlled conditions.

This study aimed: a) to compare the ability of the different mangrove species to survive extreme water stress at early stage of growth, b) to determine differences in growth performance between different mangrove species grown in different water levels and saline conditions, and c) to determine the effects of salinity and water availability on biomass allocation of different mangrove species.

\section{MATERIALS AND METHODS}

Sourcing and Collection of Mangrove Seedlings

Selected mangrove species, commonly found in the seaward zone, middle zone and landward zone namely: Rhizophora mucronata, 
Rhizophora apiculata, Lumnitzera racemosa, and Avicennia marina, respectively, were used in the study. The indicator status of these mangrove species is shown on Table 1. The mangrove seedlings were obtained from the Provincial Mangrove Nursery located at Barangay San Roque in the municipality of Macrohon, Southern Leyte, which is managed by the Local Government Unit (LGU) of Maasin City. These

Table 1. Indicator status of mangrove species used in the study (CV-CIRRD, 1993; Primavera et al., 2004; Melana and Gonzales, 1999)

\begin{tabular}{lll}
\hline \multicolumn{1}{c}{ SEAWARD } & \multicolumn{1}{c}{ MIDDLE ZONE } & \multicolumn{1}{c}{ LANDWARD } \\
\hline Avicennia marina & Avicennia alba & Avicennia officinalis \\
Rhizophora mucronata & Rhizophora apiculata & \\
& Lumnitzera littorea & Lumnitzera racemosa \\
\hline
\end{tabular}

seedlings were collected from the wild and raised in the nursery and were irrigated with pure seawater.

The seedlings were brought to the greenhouse of the Marine Laboratory at the Visayas State University (VSU), Visca, Baybay, Leyte. The mangrove seedlings were obtained from the Provincial Mangrove Nursery located at Barangay San Roque in the municipality of Macrohon, Southern Leyte, which is managed by the Local Government Unit (LGU) of Maasin City. These seedlings were collected from the wild and raised in the nursery and were irrigated with pure seawater.

The seedlings were brought to the greenhouse of the Marine Laboratory at the Visayas State University (VSU), Visca, Baybay, Leyte.

\section{Survival Rate Experiment}

Sixty seedlings per mangrove species were randomly selected for the drought experiment. Ten seedlings per mangrove species served as the control, which were watered daily. The remaining fifty seedlings per mangrove species were no longer watered to obtain different wilt stages. A pressure bomb or chamber, which measures water potential was not available for this study. Instead of using water potential as an indicator of water availability, wilting stages were used to indicate different levels of water stress. According to Abit (2008) and Engelbrecht et al., (2006), 
wilting is commonly used as an indicator of plant stress when exposed to drought.

The effect of the drought was assessed every morning by assigning each seedling to one of five visual wilting stages based on easily perceptible characteristics, such as leaf angle and necrosis as described by Slot and Poorter (2007). The five wilting stages and the control served as the treatments in this dry-down experiment (Table 2). These

Table 2. Wilting stage of the most wilted individual leaf that was used to assess survival rate (adapted from Engelbrecht and Kursar, 2003 and Abit, 2008)

\begin{tabular}{ll}
\hline \multicolumn{1}{c}{ Wilting stage } & \multicolumn{1}{c}{ Characteristics } \\
\hline $\begin{array}{l}\text { Normal } \\
\text { Slightly wilted }\end{array}$ & $\begin{array}{l}\text { No sign of wilting. All leaves green and with full turgor } \\
\text { Leaves green but leaf angled slightly toward ground compared } \\
\text { to normal seedling. } \\
\text { Leaves green but angled } 45^{\circ} \text { with some curling of the leaf } \\
\text { blade. } \\
\text { Leaves green but angled to } 90^{\circ} \text { with extensive leaf curling of } \\
\text { the leaf blade. Some necrosis on leaf margins and leaf blade. }\end{array}$ \\
Severely wilted & $\begin{array}{l}\text { Most leaves necrotic with extensive leaf curling. Some parts } \\
\text { of stem are alive as distinguished by color. }\end{array}$ \\
Nearly dead & $\begin{array}{l}\text { Necrosis on all leaves with extensive leaf curling. Leaves are } \\
\text { brittle and angled mostly to } 90^{\circ} .\end{array}$ \\
Presumed Dead &
\end{tabular}

wilting stages were strongly correlated to water potentials of seedlings during progressive drought (Tyree et al., 2003; Engelbrecht and Kursar, 2003; Abit, 2008). All polyethylene pots ( $3 \times 3 \times 8$ in.), which contained the seedlings, were soaked with saline water for a day and water was allowed to drain by gravity for 2 days. Watering was then interrupted for varying number of days that ranged from 1 to 80 days to generate different wilt stages. The progressive impact of drought on seedlings was assessed from the start of the experiment by monitoring leaf wilting, leaf rolling and necrosis every day. To better control the levels of water deficit, individual seedling was sampled at each wilting stage prior to rewatering. Ten individuals per wilting stage of the most wilted individual leaf were sampled. Subsequently, the seedlings were re-watered daily with $200 \mathrm{ml}$ sea water at $32 \mathrm{ppt}$ after drought exposure. Survival was then assessed. Seedlings with resprouts or which appear normal were considered as those that survived drought stress. Overall survival was 
defined by the presence of a shoot resprout or photosynthetically active leaf.

\section{Growth Salinity Under Different Salinity and Water Levels}

For each mangrove species, water availability and salinity was manipulated in a $3 \times 3$ factorial experiment with 5 replications per treatment consisting of 3 watering regimes (well-watered, dry, and flooded) and 3 levels of salinity (low saline, high saline, and control which is pure sea water). The mangrove seedlings were grown in sandy loam potting medium with a bulk density of $1.25 \mathrm{~g} / \mathrm{cm}^{3}$.

Using Atago hand refractometer, salinity treatments were created using pure seawater diluted to desired levels of salinity, namely; low saline (3-5 ppt), high saline (25-27 ppt), and control (pure seawater at $32 \mathrm{ppt}$ ). In order to acclimate the seedlings, these were exposed to 1.0 ppt for 3 days, 3 ppt for another 3 days and then exposed to a salinity of $5 \mathrm{ppt}$ for 2 days for the low saline treated seedlings and to $13 \mathrm{ppt}$ for another 2 days and finally to $25 \mathrm{ppt}$ salinity for the high saline treated plants. Control seedlings were exposed to $15 \mathrm{ppt}$ for 3 days and then to $35 \mathrm{ppt}$. Pots were flooded to $14 \mathrm{~cm}$ from below the soil surface to ensure saturation of the soil volume in the pots (adapted from Allen et al., 2003).

For the water treatments, plants that were assigned to well watered and flooded treatments were provided with $100 \mathrm{ml}$ water daily. The watering schedule of the flooded treatment was identical to the wellwatered, except that each pot was placed in individual containers preventing drainage of excess water. The plastic container was as tall as the pots to maintain the water level of the soil surface in each pot. Once per week in the dry treatment, plants were given $100 \mathrm{ml}$ of water (adapted from Abit, 2008).

\section{Growth Performance Parameters}

Five randomly selected seedlings per species of mangrove were harvested at the start of the experiment. Height and root length of 
the seedlings were measured and leaves were counted. Seedlings were divided into roots, stem, and leaves, and their dry weights were determined. All plant parts were oven dried for a week at $70{ }^{\circ} \mathrm{C}$ and weighed.

Monthly monitoring of plant height, number of leaves, and necrosis was done. At the end of the 3 month long growth experiment, all seedlings were harvested. Individual plant height and number of leaves were also determined. The plant samples were partitioned into leaves, stems, root and oven dried at $70{ }^{\circ} \mathrm{C}$ for a week and weighed.

\section{Statistical Analysis}

Statistical analysis was conducted using JMP version 7 Statistical Analysis System (SAS) (Cary, NC, USA). A full factorial analysis of variance (ANOVA) was used to test the effect of water and salinity levels on the different growth parameters that were gathered. When significant results were obtained, Tukey's Honestly Significant Difference (HSD) test was used to compare and determine significant differences between treatment means. To determine whether species type and wilt stages influenced the overall percent survival of each species, statistical analysis for drought tolerance data was done using nominal logistic regression of JMP version 7 (SAS, Cary, NC, USA) and was plotted using Sigmaplot 10.

\section{RESULTS AND DISCUSSION}

Survival Experiment

Different levels of water stress as manifested by the different wilt stages (Fig. 1) significantly affected the survival rates of all species. Mangrove species from different zonations also differed significantly in their survival rates after drought exposure. There was also a significant interaction effect of species by wilt stages on survival rates across all species (Fig. 2). 


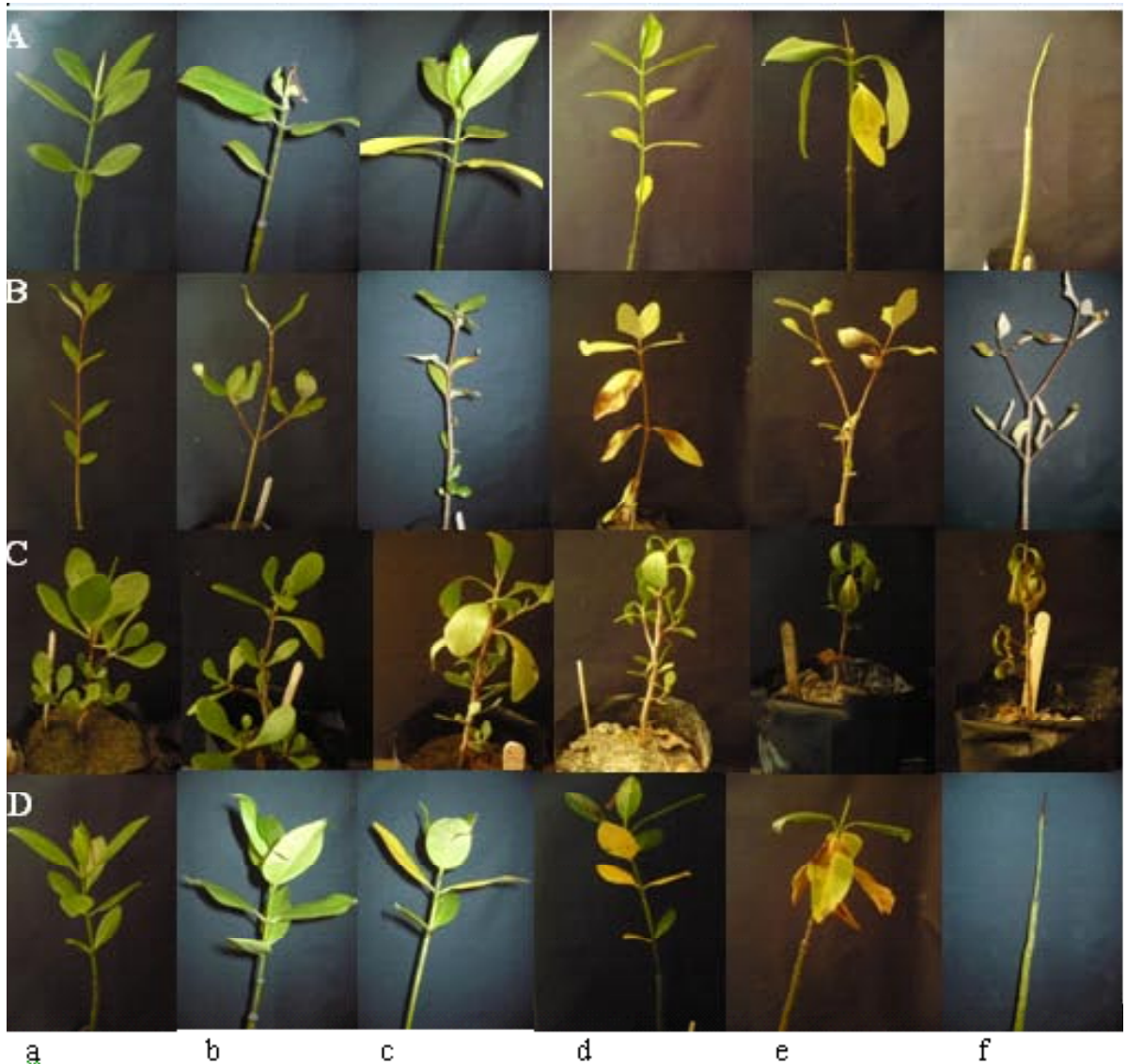

Figure 1. Wilt stages of A) Rhizophora apiculata, B) Avicennia marina, C) Lumnitzera racemosa, D) Rhizophora mucronata: a) normal, b) slightly wilted, c) wilted, d) severely wilted, e) nearly dead, f) presumed dead

The ability of the species to survive drought varied among the mangrove species used. Survival at low water availability is a drought tolerance strategy that allows plants to maintain survival and physiological processes (Tyree et al., 2003, and Slot and Poorter, 2007). A 100 percent survival was observed in all of the control seedlings. The landward species, Lumnitzera racemosa, had a significantly higher survival rate across all wilt stages relative to the middle and seaward species (Fig. 2). Rhizophora mucronata (middle zone) and Avicennia marina (seaward) had a significantly higher survival rate than 


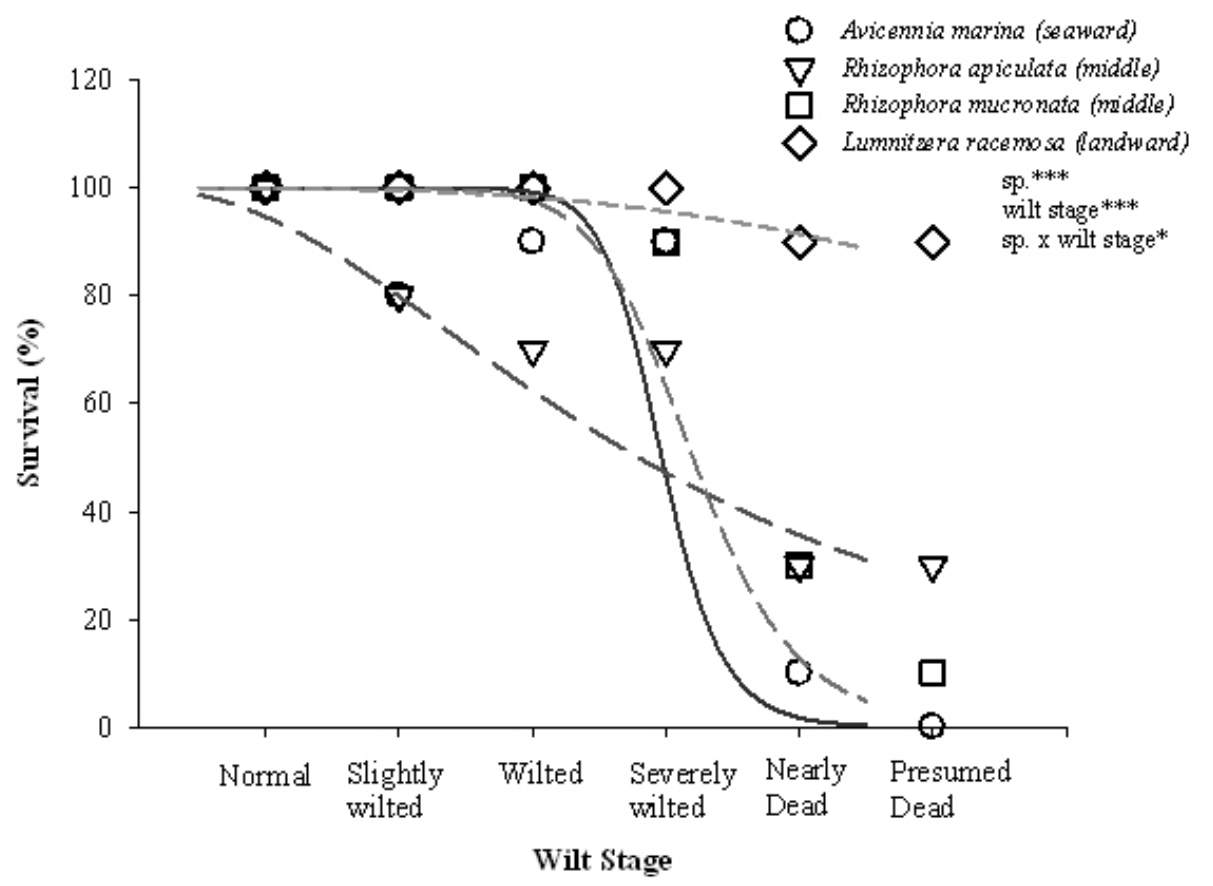

Figure 2. Survival rates of different mangrove species under various wilt stages. nsnot significant, ${ }^{*} \mathrm{p}<0.05, * * \mathrm{p}<0.01, * * * \mathrm{p}<0.005$

Rhizophora apiculata (middle zone) only up to severely wilted stage, however as wilting progressed the latter showed both survival than the two former species.

As a landward species, L. racemosa is more adapted to less moist soil (Elamry, 1998). Since L. racemosa is only inundated by periodic spring tides, their survival and growth relied on the rainfall they will receive. Thus, it is imperative for $L$. racemosa to evolve an adaptive mechanism to tolerate drought. In addition, morphological traits such as succulence and thickness of their leaves may also be attributed to less dehydration of landward species (Primavera et al., 2004). A. marina and $R$. mucronata were reported to have ability to tolerate higher salinity condition (Krauss et al., 2008). The physiological adaptations of these mangrove species to saline conditions may correspond to their adaptations to drought stress (Munns, 2002). However, this assumption should be used with caution, since in some halophytes, mechanisms 
for salt tolerance are not always related to drought tolerance (Ueda and Kanechi, 2003). Although A. marina is a seaward species, the manifestation of high survival rate up to severely wilted stage, could be attributed to their high carbon assimilation (Ball and Farquhar, 1984) and low evapotranspiration rate (Ye et al., 2005). It could then be possible that $A$. marina may have high water use efficiency (WUE), which means a high carbon gain per unit water lost during the production of biomass. Moreover, morphological modifications such as leaf curling or rolling (Chavez et al., 2003) and the presence of waxy cuticle, thick epidermis and sunken stomates of $A$. marina (Hodgkiss, 1986) may have contributed to their low evapotranspiration. Due to $A$. marina's relatively low evapotranspiration rate as observed by Ye et al., (2005), it is then possible that the salt in their cells or tissues have been diluted even if this species is continuously exposed to high saline conditions. Hence, it is expected that A. marina, could tolerate drought stress assuming that it has high WUE and the possibility of dilution of salts in their cells or tissues.

Comparing the survival rates of the two Rhizophora spp. from the same zonation, there was a highly significant difference across all wilt stages and a significant difference due to species effect and interaction effect between species and wilt stages (Fig. 3). Rhizophora mucronata had a highly significant survival rate than $R$. apiculata only up to severely wilted stage (Fig. 3). There was a sharp decline in the survival of $R$. mucronata than $R$. apiculata in the last two wilt stages. When the two congeneric species were examined in terms of their survival under drought stress, Rhizophora mucronata was more tolerant up to severely wilted stage. However, at the last two wilt stages, $R$. apiculata showed more tolerance to drought than $R$. mucronata.

During drought stress, shedding of leaves in these mangrove species may be a defense mechanism to prevent excessive water loss (Lambers et al., 1988; Engelbrecht et al., 2007). Both Rhizophora spp. shed off their leaves after dry-down. Soon after a few weeks of re-watering, the two species showed re-growth of terminal buds (Fig. 4 E-H). The regrowth of new leaves and terminal buds in the two Rhizophora spp. after drought exposure may indicate continued stem hydraulic conductivity. 


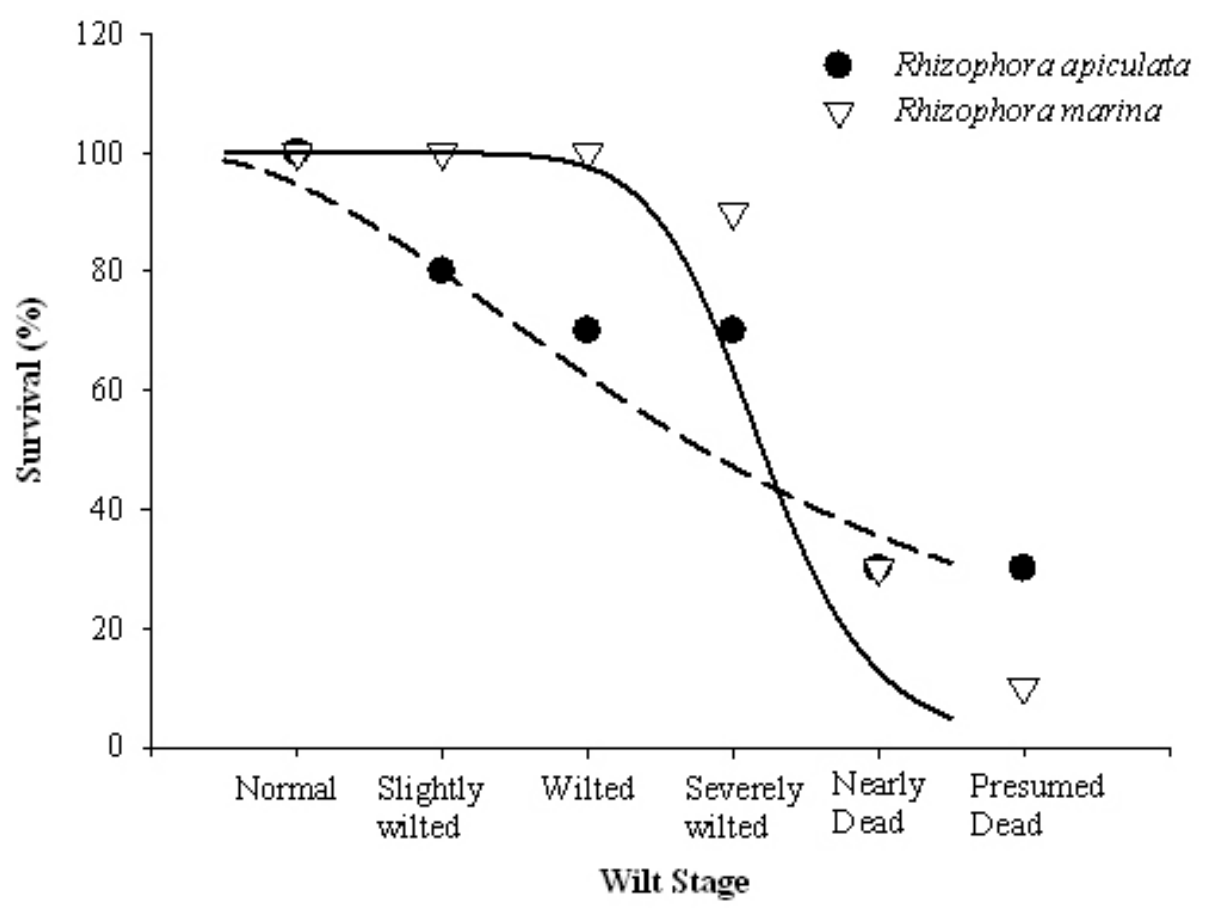

Figure 3. Comparison of the survival rates of Rhizophora species under various wilt stages. ns- not significant, ${ }^{*} \mathrm{p}<0.05, * * \mathrm{p}<0.01, * * * \mathrm{p}<0.005$

On the other hand, basal resprouting of A. marina (Fig. 4 A and B) and L. racemosa (Fig. $4 \mathrm{C}$ and D) may indicate continued root hydraulic conductivity. These functional roots are likely able to transport water to newly developed leaves at the base of the stem (Abit, 2008).

\section{Growth Experiment}

The different levels of water and salinity had been recognized as potential stressors that regulate physiological processes such as growth, height, survival and zonation patterns in mangroves (Lin and Sternberg, 1993). The four species studied did not show marked differences in their growth performance during the first month of exposure to different levels of water and salinity stresses, but were apparent in the third month. Lumnitzera racemosa, which thrives more in less moist soil (Elamry, 

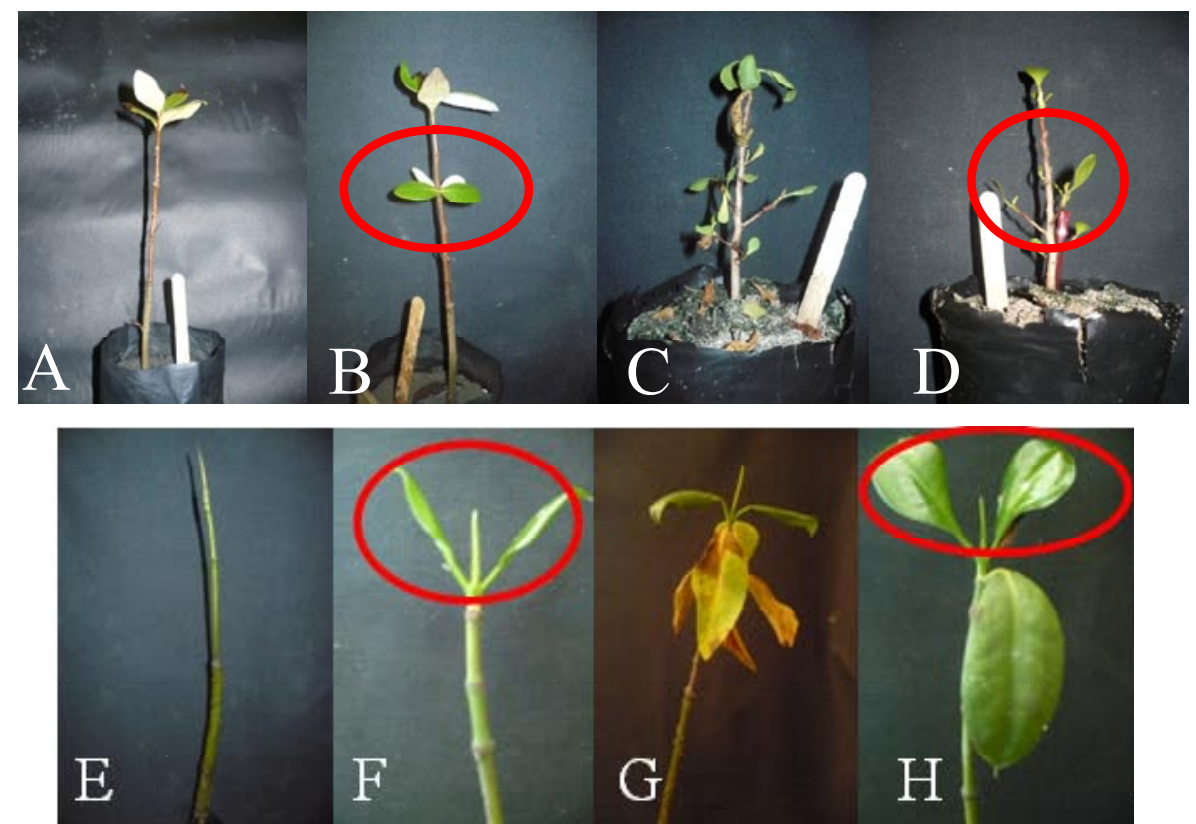

Figure 4. Survival of A \& B) A. marina, $\mathrm{C} \&$ D) L. racemosa, E \& F) R. mucronata, $\mathrm{G}$ \& H) $R$. apiculata after re-watering subsequent to drought exposure. Circles indicate new growth that occurred subsequent to re-watering after drought.

1998), did not grow well in most of the flooded treatments. Visible signs of tissue injury such as yellowing and necrosis of older leaves especially for $L$. racemosa were observed. Table 3 shows that there was a highly significant difference in the number of leaves produced between species regardless of salinity and water levels.

Table 3. Analysis of variance (ANOVA) on the number of leaves of $A$. marina, $R$. apiculata, R. mucronata, and L. racemosa as affected by water and salinity levels (3 MA)

\begin{tabular}{lcl}
\hline \multicolumn{1}{c}{ Source of variation } & Fratio & p-value \\
\hline Species & 25.334 & $<.0001^{* * *}$ \\
Water level & 4.586 & $0.0118^{*}$ \\
Species x Water level & 2.036 & $0.0650^{\text {ns }}$ \\
Salinity & 1.921 & $0.1504^{\text {ns }}$ \\
Species x Salinity & 2.780 & $0.0140^{*}$ \\
Water level x Salinity & 0.434 & $0.7838^{\text {ns }}$ \\
Species x Water level x Salinity & 1.226 & $0.2712^{\text {ns }}$ \\
\hline
\end{tabular}


Moreover, the number of leaves across species was significantly affected by different water levels and by the interaction effect between species x salinity, which is in contrast to the findings of Katherisan and Rajendran (2002) who reported that the number of leaves of $R$. apiculata was not affected by salinity treatments. The species differences in the number of leaves regardless of treatments may be due to the inherent leaf production trait of the different mangrove species, but not between congeneric species, such as the two Rhizophora species (Fig. 5). The

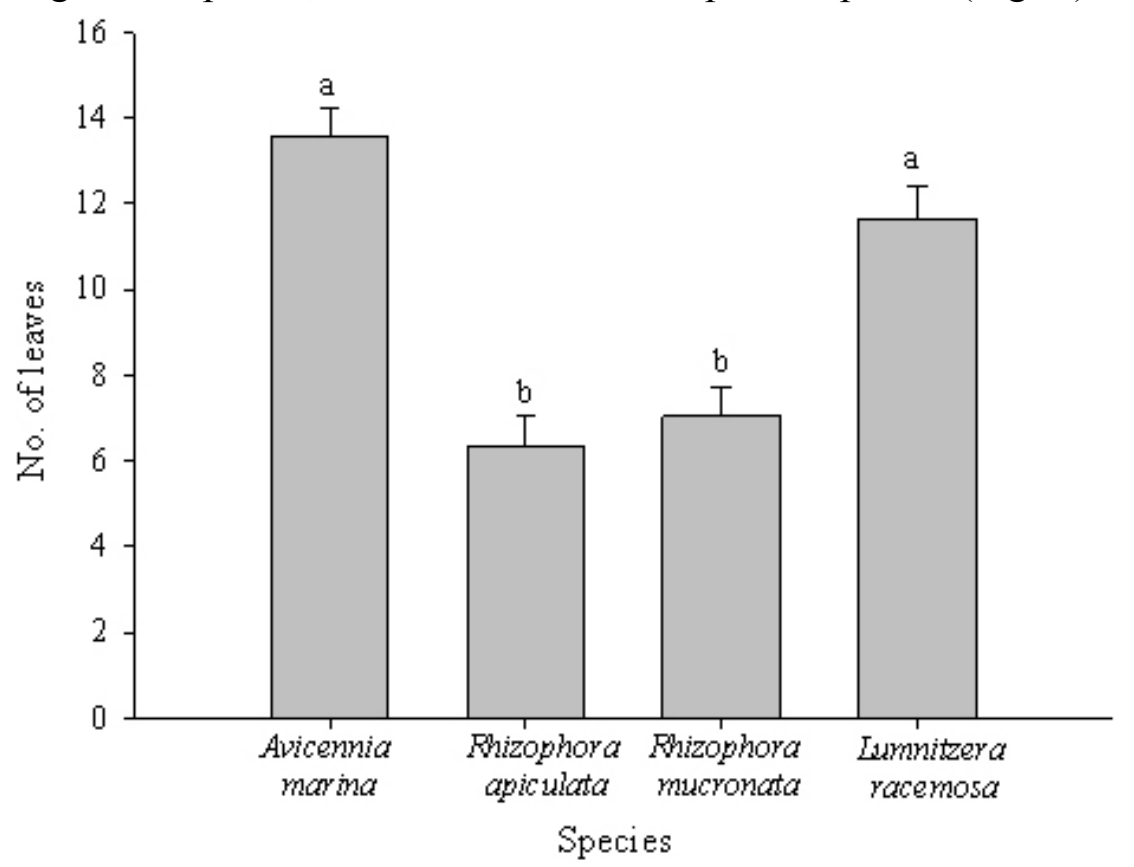

Figure 5. Mean number of leaves of different mangrove species regardless of salinity or water level treatments (3MA). Different letter above bars represent significant differences $(\mathrm{p}<0.05)$ between treatments (Tukey's HSD).

difference in leaf number as affected by different water levels could be due to the differences in the degree of tolerance of different species to water stress (i.e. flooded and drought). Leaf shedding for instance is a strategy done by most plants to survive and grow under drought conditions, but may also be costly for them to produce new photosynthetically active leaves relative to those species exposed to well-watered conditions (Lambers et al., 1998). 
The number of leaves of $A$. marina was significantly different with $R$. apiculata and $R$. mucronata, but statistically similar to $L$. racemosa across all salinity levels (Fig. 6). L. racemosa was not

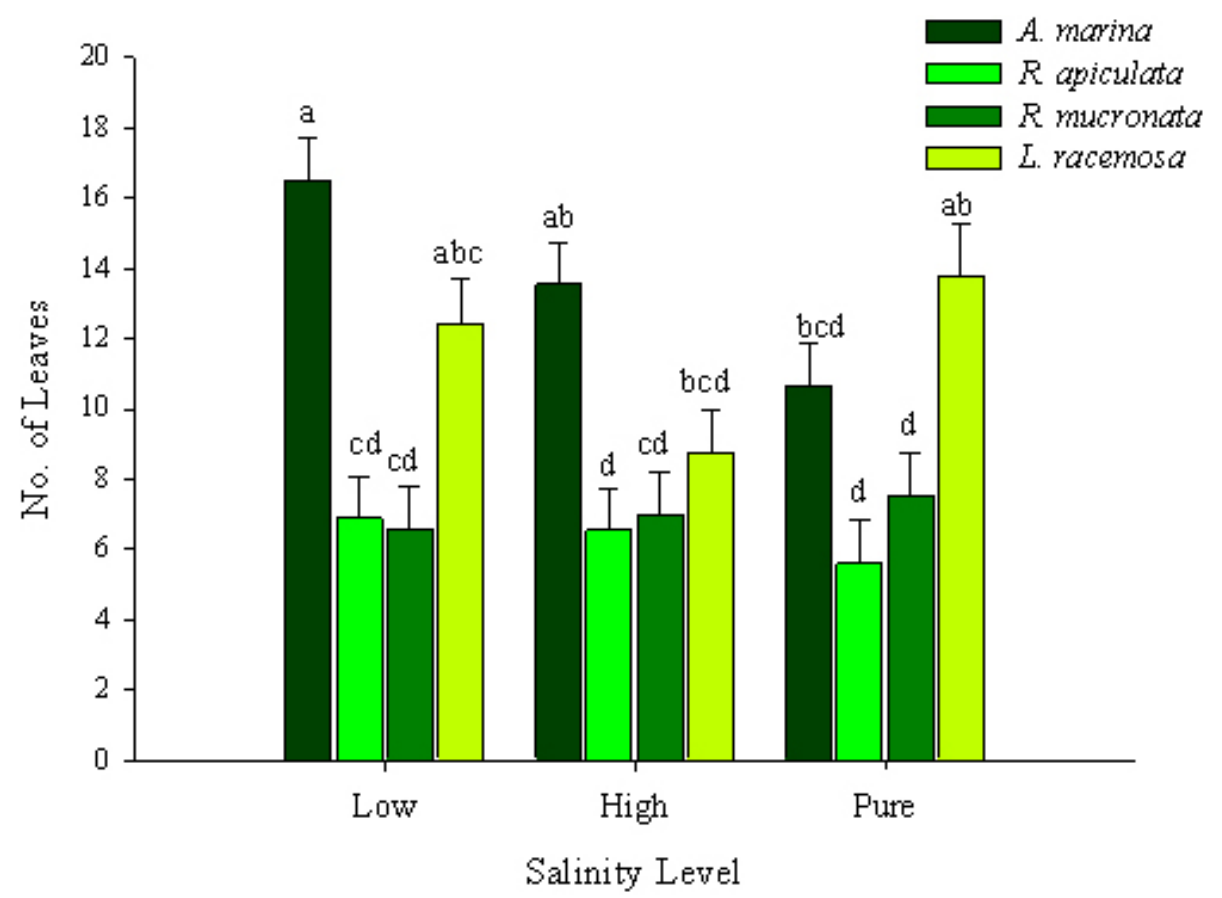

Figure 6. Effect of species $x$ salinity interaction on the mean number of leaves of different mangrove species (3MA). Different letter above bars represent significant differences $(\mathrm{p}<0.05)$ between treatments (Tukey's HSD).

significantly different from the two Rhizophora spp. except for the pure saline treatment. Moreover, $R$. apiculata and $R$. mucronata were not significantly different with each other at the three different salinity concentrations used. The significantly higher number of leaves in $A$. marina relative to the two Rhizophora spp. could be attributed to their salt tolerance (Shan et al., 2008). Thus, it would be possible for A. marina to still maintain leaf production even under saline conditions (Taiz and Zeiger, 1998). The ability to grow leaves under salinity stress (Taiz and Zeiger, 1998) may sometimes correspond to the maintenance of growth and photosynthesis under drought stress (Munns, 2002). Hence, 
L. racemosa, a drought tolerant species (Elamry, 1998) was still able to maintain leaf production even under salinity stress.

Root length was significantly affected by species and the interaction between species and water levels (Table 4). Roots of $A$. marina was

Table 4. Analysis of variance (ANOVA) on the root length of A. marina, $R$. apiculata, $R$. mucronata, and L. racemosa as affected by water and salinity level (3MA)

\begin{tabular}{lll}
\hline \multicolumn{1}{c}{ Source of variation } & Fratio & p-value \\
\hline Species & 3.4614 & $0.0181^{*}$ \\
Water level & 1.1422 & $0.3221^{\mathrm{ns}}$ \\
Species x Water level & 2.8525 & $0.0119^{*}$ \\
Salinity & 0.3059 & $0.7370^{\mathrm{ns}}$ \\
Species x Salinity & 1.2625 & $0.2787^{\mathrm{ns}}$ \\
Water level x Salinity & 0.4847 & $0.7470^{\mathrm{ns}}$ \\
Species x Water level x Salinity & 0.8755 & $0.5733^{\mathrm{ns}}$ \\
\hline
\end{tabular}

significantly longer than $R$. apiculata but statistically similar with $R$. mucronata and L. racemosa regardless of water level and salinity treatment (Fig. 7). Root length of $R$. apiculata, $R$. mucronata and $L$. racemosa was not significantly different. The capability of increased root growth in A. marina, L. racemosa and R. mucronata (Fig. 8) could be related to their greater ability to withstand drought stress relative to R. apiculata (Fig. 2). According to Pritchard (1994) and Fry et al. (1992), wall loosening may be possible due to the increase in the xyloglucan endotransglycosylase (XET) enzyme, which is involved in wall loosening, as induced by abscissic acid (ABA) accumulation in plants under water stress. This increased wall loosening capacity is a response to drought stress (Pritchard, 1994) that may possibly allow the roots of A. marina, L. racemosa and $R$. mucronata to exploit water in drying soils.

Plant height was not significantly different among species; however, effect of water levels and salinity concentrations was highly significant. Likewise, interaction effect between water and salinity level on growth was significant (Table 5). 


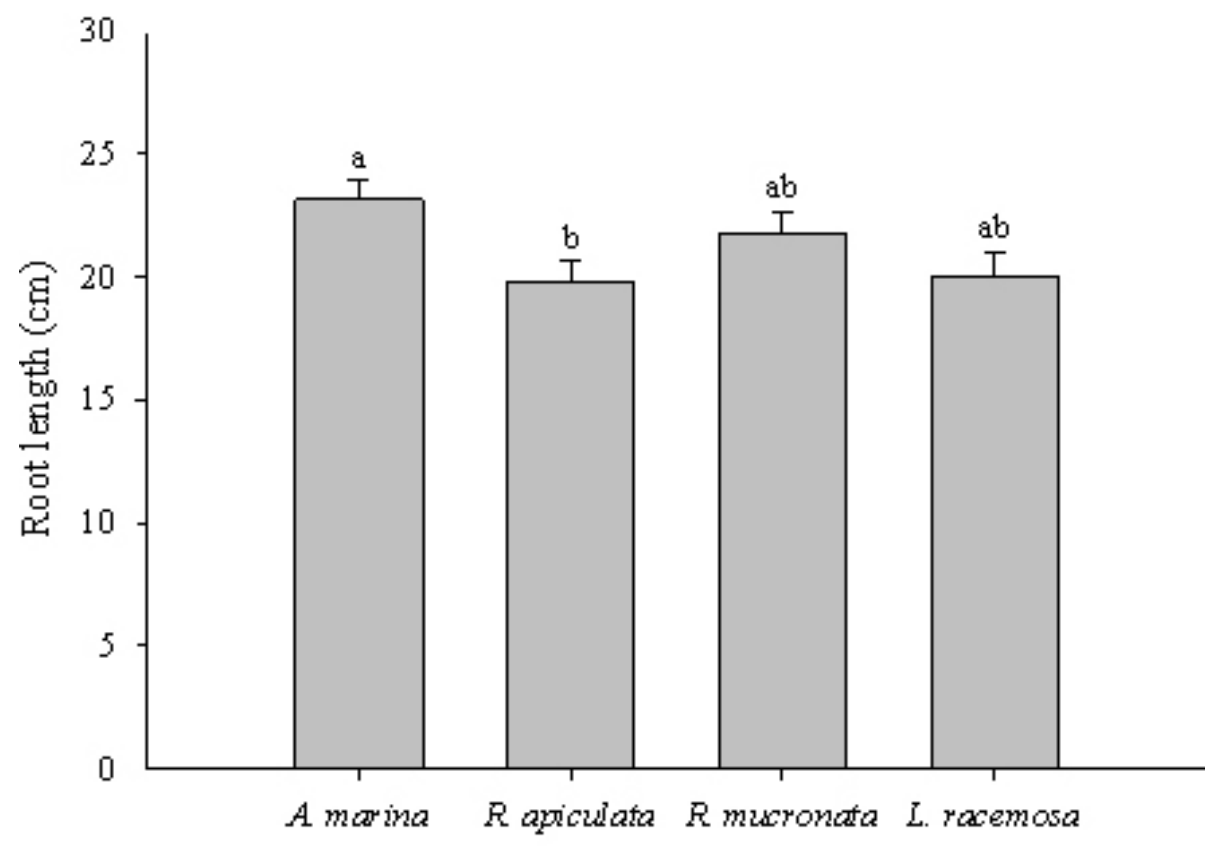

Species

Figure 7. Mean root length of different mangrove species regardless of salinity and water level treatments (3 MA). Different letter above bars represent significant differences $(\mathrm{p}<0.05)$ between treatments (Tukey's HSD).

Root:Shoot biomass ratio was not significantly affected by species and different water and salinity levels. According to Biber (2006), it may take a little more time to achieve significant results on looking at the effects of water and salinity stress on the growth parameters such as biomass allocation. Moreover, the physiological adjustment by individual mangrove species to compensate for the decline in their growth performance after exposure to stress may take some time, although it always occurs within their entire life cycle (Lambers et al., 1998). Hence, the time scale to exposure to stress and the different mechanisms that control growth and biomass accumulation may happen at a different period of time or in a later period for the mangroves used in this study. 


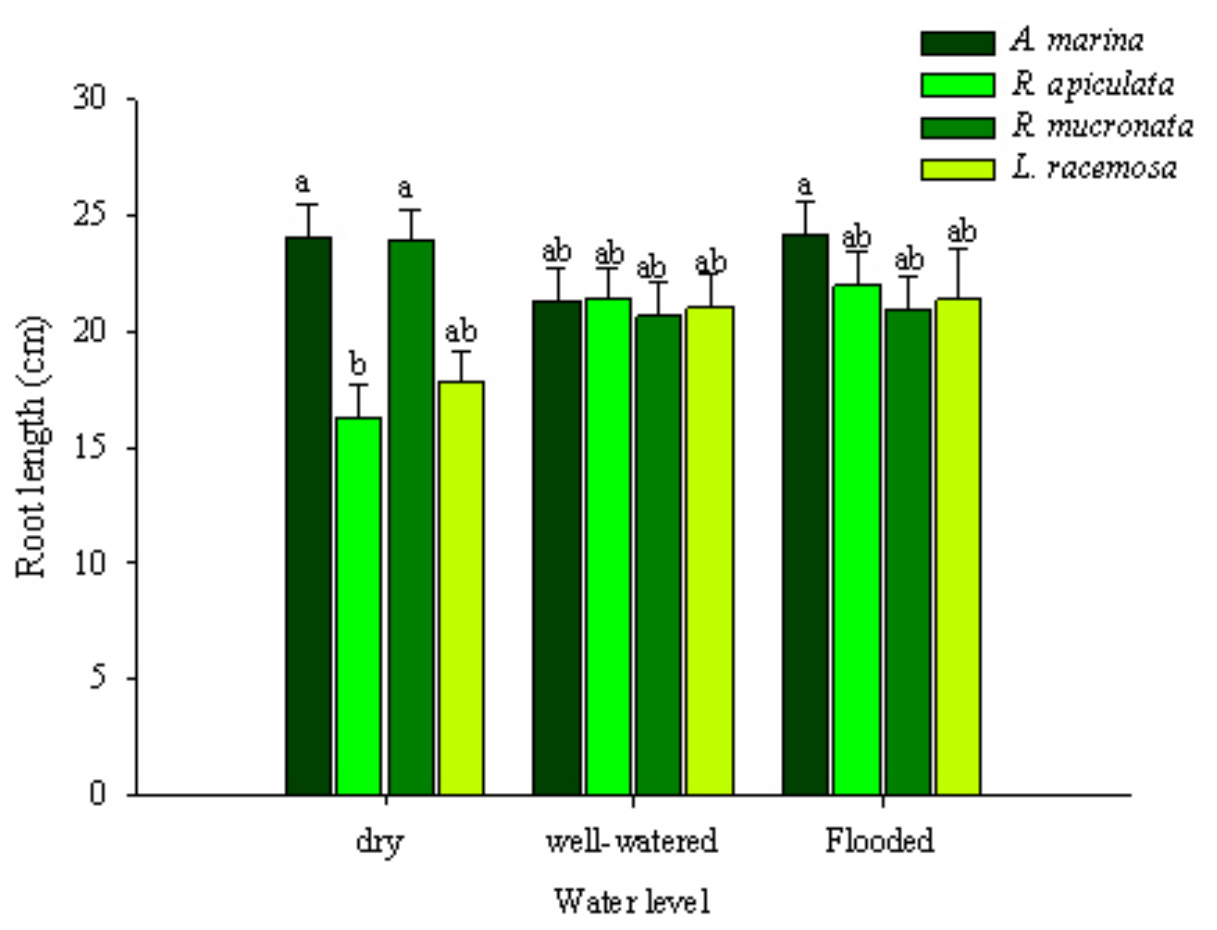

Figure 8. Effect of species $\mathrm{x}$ water level treatment on the root length of different mangrove species (3 MA). Different letter above bars represent significant differences $(\mathrm{p}<0.05)$ between treatments (Tukey's HSD).

Table 5. Analysis of variance (ANOVA) on the growth rate of A. marina, R. apiculata, $R$. mucronata, and L. racemosa as affected by water level and salinity (3 MA)

\begin{tabular}{lcc}
\hline \multicolumn{1}{c}{ Source of variation } & F ratio & p-value \\
\hline Species & 1.2027 & $0.3118^{\mathrm{ns}}$ \\
Water level & 14.5767 & $<.0001^{* * *}$ \\
Species x Water level & 1.8269 & $0.0993^{\mathrm{ns}}$ \\
Salinity & 12.6643 & $<.0001^{* * *}$ \\
Species x Salinity & 1.8335 & $0.0980^{\mathrm{ns}}$ \\
Water level x Salinity & 2.7019 & $0.0336^{*}$ \\
Species x Water level x Salinity & 1.6066 & $0.0962^{\mathrm{ns}}$ \\
\hline ns- not significant, ${ }^{*} \mathrm{p}<0.05, * * \mathrm{p}<0.01, * * * \mathrm{p}<0.005$ &
\end{tabular}




\section{CONCLUSION AND RECOMMENDATION}

Lumnitzera racemosa was the most drought tolerant across all wilt stages while $R$. apiculata was the most drought sensitive to drought stress up to severely wilted stage. Between congeneric species, $R$. mucronata was more drought tolerant than $R$. apiculata up to severely wilted stage. The ability of $L$. racemosa and $R$. mucronata to tolerate drought corresponded to their current distribution in the wild, but not for the other two mangrove species studied. For instance, A. marina, which are subjected to daily tides and flooding showed tolerance to physiological drought, although this species is always found submerge in sea water.

Drought stress may potentially cause a shift in mangrove vegetation distribution. There is a possibility that $A$. marina may displace the current distribution of $R$. apiculata in the middle zone as manifested by its high survival rate under drought stress while the distribution of L. racemosa and $R$. mucronata in the landward and middle zone, respectively could be retained.

It can be deduced that $A$. marina, $L$. racemosa, and $R$. mucronata are better able to grow under water and salinity stresses as manifested by the maintenance of leaf production and root growth. A. marina and $L$. racemosa also maintained greater leaf production even under salinity stress. A. marina, L. racemosa, and $R$. mucronata produced longer roots than $R$. apiculata under different water levels, which corresponded to their drought tolerance. Water and salinity stresses did not affect the biomass allocation of the different 3 month old mangrove seedlings. It is therefore recommended that a long-term growth experiment be done to get desired results.

Future studies must be conducted to complement our findings such as: a) determination of other physiological traits that the mangrove species may possess to be able to withstand water stress, b) determination of cavitation resistance, wood density and hydraulic conductivity of the mangrove species, and c) morphological and anatomical characterization of the mangrove species after exposure to water stress. 


\section{ACKNOWLEDGMENT}

The main author wishes to thank Dr. Lelita R. Gonzal and Prof. Analyn M. Mazo for their valuable suggestions and comments.

\section{REFERENCES}

ABIT, P. P. 2008. Ecological and Physiological Basis for the Distribution of Woody Plants along Water Availability Gradients in the Southeastern United States Mixed Forest. PhD Thesis, North Carolina State University, Raleigh, North Carolina.

ALLEN, J. A., K. W. KRAUSS, and R. D. HAUFF. 2003. Factors limiting the intertidal distribution of the mangrove species Xyclocarpus granatum. Oecologia 135:110-21.

BALL, M. C. 1996. Comparative Ecophysiology of Mangrove Forest and Tropical Lowland Moist Rainforest. Tropical Forest Plant Ecophysiology. Chapman and Hall, pp. 461-487.

BALL, M. C. and S. M. PLIDSLEY. 1995. Growth responses to salinity in relation to distribution of two mangrove species Sonneratia alba and S. lanceolata in Northern Australia. Functional Ecol. 9(1):77-85.

BALL, M. C. and G. D. FARQUHAR. 1984. Photosynthetic and stomatal responses of two mangrove species, Aegiceras corniculatum and Avicennia marina to Long-term salinity and humidity conditions. Plant Physiol. 74:1-6

BIBER, P. D. 2006. Measuring the effects of salinity stress in the red mangrove, Rhizophora mangle L. African Journal of Agricultural Rev. Hydrobiology 1(1):1-4. 
BOTO, K. G. 1987. Nutrient and Organic fluxes in Mangrove Ecosystems in Australia. Australian National University Press, Canberra, pp. 239-257.

CALUMPONG, H. P. and E. G. MENEZ 1997. Field Guide to the common Mangrove Seagrasess and Algae of the Philippines, pp. $1-10$.

CHAVEZ, M. M., J. P. MOROCCO, and J. S. PEREIRA. 2003. Understanding plant responses to drought from genes to the whole plant. Functional Plant Biology 30: 239-264.

CLARK, J. R. 1992. Integrated Management Zone. FAO Fisheries Technical paper no. 327:26.

CLARKE, P. J., R. A. KERRIGAN, and C. J. WESTPHAL. 2001. Dispersal potential and early growth in 14 tropical mangroves: do adult early life history traits correlate with patterns of adult distribution? J. Ecol. 89:648-659.

CLARKE, P. J. and P. J. MYERSCOUGH. 1993. The intertidal distribution of the grey mangrove (Avicennia marina) in Southeastern Australia: The effects of physical conditions, interspecific competition, and predation on propagule establishment and survival. Austral. Ecol. 18:307-315.

CV-CIRRD (Central Visayas Consortium for Integrated Regional Research and Development). 1993. Mangrove production and management. Central Visayas Technology Transfer Guide, CVCIRRD, Cebu City, Philippines. pp. 5-8.

DAWNES, C. J. 1998. Marine Botany, 2nd ed. University of South Florida Tampa, Florida. pp 84-87.

DODD, G. L. and L. A. DONOVAN. 1999. Water potential and ionic 
effects on germination and seedling growth of two cold desert shrubs. American Journal of Botany 86:1146-1153.

DOUBENMIRE, R. F. 1974. Plants and Environment, 3rd ed. A textbook of Plant Autecology. Washington State University. pp 47-56.

ENOKI, T., M. VEDA, D. NANKI, R. SUWA, and A. HAGHARA. 2009. Distribution and stem growth patterns of mangrove species along the Nakara River in Iriomote Island, Southern Japan. $J$. For. Res. 14:51-54.

ENGELBRECHT, B. M. J. and T. A. KURSAR. 2003. Comparative drought resistance of seedlings of 28 species of co-occuring tropical woody plants. Oecologia 136:383-393.

ENGELBRECHT, B. M. J., J. W. DALING, T. R. PEARSON, R. L. WAF, D.A. GALVEZ, T. KOEJILER, M. T. TYREE, and T.A. KURSAR. 2006. Short dry spells in the wet season increase mortality of tropical pioneer seedlings. Oecologia 141:258269.

ELAMRY, M. 1998. Population structure, demography and life tables of Avicennia marina (Forssk.) Vierh. at sites on the eastern and western coasts of United Arab Emirates. Marine Freshwater Res. 49(4):303-308.

FRY, S. C., R. C. SMITH, K. F. RENWICK, D. J. MARTIN, and S. K. HODGE. 1992. Xyloglucan endotransglycosylase, a new wallloosening enzyme activity from plants. Biochem J. 282:821828.

HODGKISS, I. J. 1986. Aspects of mangrove ecology in Hongkong. Memoirs of the Hong Kong Natural Society 17:107-116.

KATHERISAN, K. 1996. Ecology and environment of mangrove 
ecosystems. Centre of Advanced Study in Marine Biology Annamalai University. pp. 101-106.

KATHERISAN, K and N. RAJENDAN. 2002. Growth of a mangrove (Rhizophora apiculata) seedlings as influenced by $\mathrm{GA}_{3}$, light and salinity. Rev. Biol. Trop. 50(2):525- 530.

KRAUSS, K. W., C. E. LOVELOCK, K. L. MCKEE., L. L. HOFFMAN., S. M. L. EWE, and W. P. SOUSA. 2008. Environmental drivers in mangrove establishment and early development: A review. Aquatic Botany

LIN, L. M. and L. S. L. STERNBERG. 2007. Nitrogen and phosphorus dynamic and nutrient resorption of Rhizophora mangle leaves in South Florida, USA. Bulletin of Marine Science 80(1):159169.

LIN, G. and L. S. L. STERNBERG. 1993. Effects of salinity fluctuation on photosynthetic gas exchange and plant growth of the red mangrove (Rhizophora mangle). J. of Experimental Botany 44:9-16

LAMBERS, H., F. S. Chapin III, and L. T. PONS. 1998. Plant Physiological Ecology. Springer-Verlag, p. 110.

MELANA, E. E. and H. I. GONZALES. 1996. Field Guide to the Identification of some Mangrove species in the Philippines. DENR Region VII. p. 1.

MUNNS, R. 2002. Comparative physiology of salt water and water stress. Plant Cell and Environment 25:239-250.

PRIMAVERA, J. H., R. B. SADABA, and M. J. H. L. LEBATA, and J. P. ALTAMIRANO. 2004. Handbook of Mangroves in the Philippines - Panay. SEAFDEC Aquaculture Department, Iloilo, Philippines. pp. 5-8. 
PRITCHARD, J. 1994. The control of cell expansion in roots. New Phytol. 127:3- 27.

SLOT, M., and L. POORTER. 2007. Diversity of seedling response to drought. Biotropica 39(6):683-690.

SHAN, L., Z. RENCHAO, D. SUISUI, and S. SUHUA. 2008. Adaptation to salinity in mangrove: Implication on the evolution of salttolerance. Science in China Press Springer 53:11.

TAIZ, L and E. ZEIGER. 1998. Plant Physiology 2nd edition. Sinauer Associates, Inc., Publishers. Sunderland, Massachusetts. p. 128.

TYREE, M. T., B. M. J. ENGELBRECHT, G. VARGAS, and T.A. KURSAR. 2003. Desiccation tolerance of five tropical seedlings in Panama: Relationship to a field assessment of drought performance. Plant Physiology 132:1439-1447.

UEDA, A. and M. KANECHI. 2003. Photosynthetic limitations of a halophyte sea aster (Aster trifolium L.) under water stress and $\mathrm{NaCl}$ stress. J. Plant. Res. 116:65-70.

YE, J., N. F. Y. TAM, C. Y. LU, and Y. S. WONG. 2005. Effects of salinity on germination, seedling growth and physiology of the three salt- secreting mangrove species. Aquatic Botany 83(3): 193 - 205 (3). 